\title{
In the Steps of Christian Doppler
}

\author{
By Professor Alec Eden, \\ President of the Christian Doppler Foundation, Salzburg.
}

\section{クリスチャン・ドプラの歩み}

1992 年 5 月 25 日ドプラ効果発見 150 周年記念にあたりプラハの貴族ボへミア会会議室での講演

\author{
Alec Eden 教授 \\ クリスチャン・ドプラ協会 会長（ザルッブルグ）
}

私達は今日, ちょうど 150 年前のこの日の 5 月 25 日の 発表を記念してこのボへミア会会議室に集まりました. 39 歳にもならないうちから体をひどくこわしていた, ザルツブルグ出身の謙虚で内気な物理学者ドプラは, 同 じように謙虚な 6 人の学者に自分の一説をこの会議室で 発表しました. 2 年前にボへミア会の一員に自分を推薦 してくれた助言者のベルナード・ボザルノや彼の友人に よって 会議が進行されていたにもかかわらず，クリス チャン・ドプラは神経質になっていました，というのは， 結局彼はその会の準会員にすぎず，この発表が自然科学 部門において彼の最初の発表であったからでした。

会員はおそらくドプラが “二重星と天の星々が放つ彩 色された光”について発表すると思っていました. また その発表が, 科学に特別に重要な効力を及ぼすものだと は考えていませんでした. 彼の論理, つまりブラッドリ 一の光行差の説を応用した説は，はたして仲間から同意 されるだろうか, 彼の観察はすべて正しいだろうか, 彼 の仮説は知らずのうちに忘却されていってしまうのでは ないかという不安がありました.

やはり彼の説は何人かの学者によって反論されました. 彼はジュセフ・ペッツバルのように公認された科学者に よる反論に対し，10 年以上も自分の説を守り続けまし た.

また彼の観察は，すべて星々の放つ光の性質である虚 像に基づくものでありましたが，その観察は間違ってい
るとされました.

しかし彼の説は自然のうちに忘却されるものではあり ませんでした. それは科学の歴史において画期的な出来 事となったのでした。 今日は, 私達が祝う歴史的記念日 というだけでなく, ドプラ効果が天文学, 航海学, その 他の近代科学や技術に計り知れない実戦力になったので した. 医学における初のドプラ効果の応用は, 120 年後日 本の研究者里村氏と金子氏による非侵襲的診断分野に応 用されました. さらに 30 年後, 金子仁郎教授はクリスチ ヤン・ドプラ協会の初代会長に選ばれました。超音波は 世界中で死を目前にした患者の延命に役立ち，生活の質 の改善に貢献しました。 このことが今日, 私達が祝う重 要な理由です.

私のクリスチャン・ドプラの生涯についての興味は, アメリカの大学において微細な脳手術におけるドプラ断 層法の利用について講義の準備課程で深まっていきまし た. 私は, この新しい医学専門分野を創った科学者の偉 大性についてこの会であらかじめ触れておきたいと思い, いくつかの辞典や科学人物辞典などを調べました. そう しているうちに私が見つけた情報が, 辞典によりくい違 っていたので大変迷いました，1つの辞典にはドプラは, アメリカの数学者とあり, ある辞典にはオーストリア生 まれでアメリカ在住の数学物理学者, あるいはドイツ人 と書かれ, 生まれは “ドイツ・ザルツブルグ"と書いて ありました. くい違いはドプラの出身地だけにとどまら 


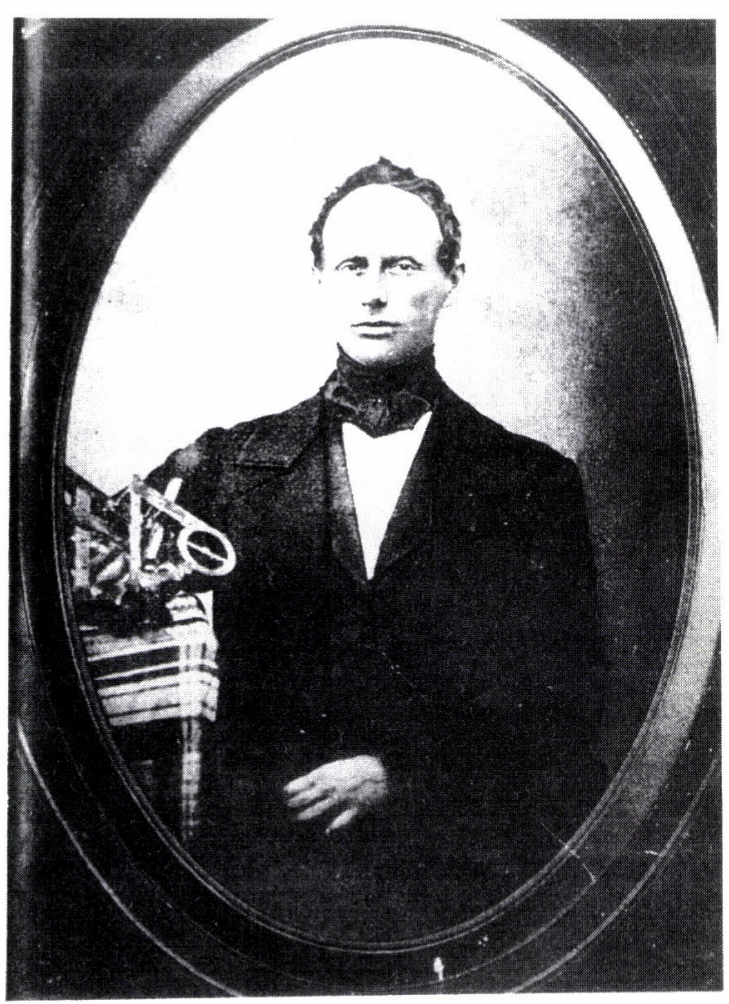

ず生年月日も違っていました。ほとんどの辞書は彼のこ とを"クリスチャン・ヨハン・ドプラ”と書いており, 数種類の辞書には “ヨハン・クリスチャン・ドプラ”と 書いてありました。 大変有名な反面, クリスチャン・ド プラその人はあまりにも知られていないことがわかりま した.

この科学者ドプラの研究のためザルツブルグに最初に 訪れたとき，この印象はさらに強くなりました.1605 年 の最も古い記録にあるようにドプラという石屋の家系図 記録はたくさんありましたが, ザルツブルグの多くの人 はドプラという有名な科学者を聞いたことがないように 思われました。ドプラの生まれた家はまだ立派に建って おり，1792 年にドプラの祖父ジョセフによって建てられ て以来ほとんど変わっていませんでした，記念の石碑に は,確かにドプラはこの家で 1803 年 11 月 29 日に生まれ たと記されていました. しかし, その家はドプラ家とし て知られているのではなく, ドプラ家がいなくなった後, 今世紀の始めまでその建物でビジネスをしていた"ジエ チェルスバーガーの家”として知られていました。今ま で人びとが思っていたように，ドプラの家はクリスチャ ン・ドプラ広場に建つているのではありませんでした。 それは比較的無名の画家，ハンス・マカルト $(1840 \sim 1884$ 年)にちなんで名付けられた広場でした。クリスチャン
・ドプラ通りの方は，ザルツブルグの古い美しい町並み の中心部にあるのではなく，第 2 次大戦中ガス工場とな つていたため醜く襲撃を受けたあと作られ，全く目立た ない町の片隅にあります。

ここザルツブルグにおいて，私は少なくともドプラの 誕生の記録と, ドプラが聖アンドラ教会で洗礼を受けた 記録を得ることができました。そして辞書にでているク リスチャン・ヨハン・ドプラまたあるときはヨハン・ク リスチャン・ドプラは, 実際は生後 4 時間後に洗礼を受 けたクリスチャン・アンドリアス・ドプラだったのです。

その青年ドプラは石屋の家族の一員として働き，その 才能は工芸品に表われています。しかし体の小さかった クリスチャン・ドプラは肉体労働が要求されるこの仕事 についていけず, 彼の父は帳簿作りの方が向いていると 考えました。はたして彼の息子が本当に会計に適してい るかどうか確かめるため, 父はザルツブルグ講堂で数学 を教えていたシモン・スタンファーを招きました。 スタ ンファーはすぐにドプラの才能を見抜き, 彼に自然科学 を勉強させるためにウイーンに出すべきだと勧めました。 ウイーンで彼は勤勉さで名をあげましたが, 彼が後に呼 ぶ“一面教育”について満足できなかつたので, 1825 年 21 歳にして彼は出身地ザルツブルグに帰りました。ルペ ルティナム会堂で数学と物理を教えて生計を立てながら, 時間の半分は以前のように勉強をしました。時には現代 言語のフランス語, イタリア語や英語を学んだり, 地元 の商業の家で商業経理を学んだりしていました。

哲学を修得した後，1829 年にドプラはウィーンに戻 り，その1年前までザルツブルグ学校で彼に高等数学を 教えていたアダム・フォン・バーグの助手になりました。 最初の助手としての契約期間の 2 年は 4 年に延ばされ, この時初めてドプラはウィーン工科学校の卒業雑誌に 4 つの科学研究を発表しました。最初の発表は1832 年の “相似理論への貢献”でした。彼はまたそこで生徒達に 有料で基礎数学を教え，さらに教師になることを望み始 めました.しかし1833 年にウィーンを離れる時には彼は その望みを果しておらず，翌年はドプラの人生において 一番のどん底でした。彼はレイサ川の土手近くのウオチ エル会社の綿工場で事務員として働くことを余儀なくさ れました。

落胆し気落ちした被は，コーロッパで教師としての職 を得る望みを完全に諦めました。そして彼の兄弟のヨ八 ンのミュンヘン出張旅行に同行しました。そこで彼はア メリカ新大陸で教師の職を得られるかどうかについてア メリカ領事と話すことができました、彼はアメリカに行 く旅費を捻出するために, 本を含め, すべての持物を売 り払いました。アメリカへの出発が目前に迫った 1835 年 
2 月，旅先のミュンヘンで彼は 2 つの職が募集されてい ることを聞きました.1つは，ベルン(スイスの首都)の 小学校の数学の教師で，もう1つはプラ八の実科学校の 基礎数学と商業経埋の教授職でした。スイスでの職はか なり高給でしたが，愛国心が強いドプラは 1835 年 4 月 30 日，年俸 800 フロリンで，プラ八のゴールデンシティ 一での職につくことを選びました。 ドプラには実はその 時すでに 20 年余の人生しか残されていませんでしたが, その日は彼の人生の絶頂期の姶まりでした。

次の年の 1 月にはすでに彼の収入は 1000 フロリンに 上げられ，この安定した経済的収入があったためか，彼 はザルツプルグに結婚のために短期間戻ることを決意し ました. 1836 年 4 月 11 日, 彼はザルツブルグの銀細工師 の娘マチルディ・ストラムとムルの教会（教会のいたる 所は彼の先祖達が工芸した大埋石で埋められていた）で ベネディクト派神父のミヒャエル・フィルツによって結 婚式を挙げました．マチルディ・ドプラは "静かな奥深 い性格” と表現され，そしてさらに天文学者カール・ク レイルは母として最高の誉め言葉であろう "最も家庭的 性質”と表していましたが，彼女は彼の科学的思想は全 く理解できませんでした。

プラ八に戻った後，彼は教えていた学校の近くにあっ たオストロブニ通りの外れの 146 番地の近代的学士寮か ら，22 番地の一軒家に移り最初の家庭を築きました。そ こが今のユングマノバと呼ぼれている所でした. 1837 年 1 月 22 日， 5 人の子供のうちの長女がそこで生まれまし た。名前は母の名を取りマチルディと名付けられました。 このころクリスチヤン・ドプラはプラ八工科大学（今の チェコスロバキア工科大学) で上級数学そして実践図形 学の非常勤講師になりました. そしてプラ八での 12 年間 で彼が発表した 35 の科学研究のうちの最初の 3 つが次 の年 "バンムガルトナーの物理と数学" に発表されまし た.

舞台は，家庭での幸福と学間的功績がすばらしく実を 結ぶためにセットされたようでした。そしてこの場を借 りて私は，自然の性質を見つけだしたドプラの科学的発 想による限りのない業績についての話しを少しでもでき たら幸いです．ところで彼の家庭生活からの喜びと学問 の道におけるフラストレーションとは，全く逆のもので あったことは事実です。

結婚後ザルツブルグからプラハに戻った 1836 年に, ド プラはライバッハ，ゲルツや他の君主国の町での職に応 募しました。そして翌年 1837 年ウイーンの工芸学校で, 上級数学の教授であるアダム・フォン・バーグ教授の面 接と試験を受けましたが失敗したために，プラ八にいる 間ドプラは何回もその試験に挑戦しました。そしてその
年の後半にようやくプラ八工科大学の非常勤講師になり ました。

ドプラの一番の疲労と不満は, 400 人の生徒に 8 週間 の授業と，そしてだれの手助けもなく，一人で 400 人一 人一人にテストを施行するというありがたくない教育の 重荷からでありました。ザルツブルグで石屋の子として ほこりっほい環境の中で育ったため，慢性の気管支病が あり，虚弱な彼にとってはあまりにも辛い仕事でした。 カール・クレイル著書の本の中には "ドプラの病状はプ ラ八ですでに始まっており，小さなこみあった教室で多 数の生徒を前に，多くの授業をしていたことが彼の健康 に打撃を与えた”と書いてあります。

1841 年, プラ八工科大学で常勤講師となりましたが, すでにきつかった仕事がさらにきつくなり，800人の生 徒の 668 のレポート採点がありました，彼の主治医であ るヨハン・フォン・オポルツア医師は後に “もしあなた が気管をだめにして死にたくなかったら，すぐにその仕 事を止めたほうが良い” と助言しました。そしてその年 の終わりにドプラは，気管支結核のため話すことができ なくなり，仕事をやめなければなりませんでした。しか し彼の家族は，彼を激励しそして 喜びを与え続けまし た. 1838 年長男ルドウイグの誕生の後, 現在カラロボ・ ナメステイの警察所と裁判所が建てられている場所にあ った一軒家に移りました。記念碑には（ドプラの死はま ちがって 1854 年と記してある） 1842 年の彼の有名な発 表はこの家でなされたと記してあります。しかし事実は, 次男アドルフの誕生後, 現在のドロウハ通り 922 番地の 家に移り，その家で今日私達がたたえる偉業が成されま した.

また 1840 年には, 以前の教職の仕事では得られなかっ た刺激と満足感を得られる教授職につくことができ，そ の年の 6 月 28 日 7 対 5 の賛成でボへミア科学会の準会 員になりました，彼の体力は衰え，きつい仕事には耐え られなくなっていたにもかかわらず，彼の家族により得 られた慰めは，彼に体力的衰えと精神的苦痛を乗り越え る力を彼に与えました。それにより彼は，ボへミア会の 活動に強い情熱を注ぎました，彼は距離を測るためのダ イアストメータと呼ばれる新しい光学機械についての論 文を夜通し書きました，回転媒体での光と音の収差につ いてや天文学での写真撮影方法の応用について論じてい ます．彼は聴覚とプラトーとスタンファーのストロボス コープに聴覚と投光とをうまく組み合わせて, 電気学, 地球物理学，天文学等における他の間題とともにボへミ ア会に発表しました。 150 年前の今日, 自然科学の会議で クリスチャン・ドプラはその理論を発表し，ドプラの名 はドプラ効果として世界中に広まりました。その会議室 
にいた 6 人のメンバーに向って，演説をしたその男は一 体何者なでしょうか. 科学者としてのドプラの活動は, 50 冊以上の論文発表に書かれています。それにしてもク リスチャン・ドプラという人はいったいどういう人なの でしょうか.

不幸にもドプラの容貌についてはあまり書かれていま せん(そのころシュミッツとして知られていた). バンス カ・スティアブニカでの時期にドプラの助手をしていた カーレル・コリストカによると, ドプラは背が高く細く, その大きな目は普通の人よりもはるかに輝いていた，と 描写されています。しかしドプラは大変内気であまり友 人もいなかったので, 彼の本当の姿について書かれたも のはほとんどありません，1853 年に亡くなった時でさ え, 王室科学アカデミーの秘書であったアントン・シュ ッレッターが，ウイーンでのアカデミー記念会議におい てドプラの人間性について述べようとしましたが，その 情報を探すことは大変難しいようでした。ボへミア科学 会に彼を推薦し，その会の議長も努めていたプラ八で唯 一の友人，ベルナルド・ボルザノは，ドプラの死の 5 年 前に亡くなっています. ドプラのもう一人親友であり， 哲学者で教育設立者のフランツ・イクスナーもそのとき にはすでにパデュアに埋葬されていました。

プラ八そしてウイーンでドプラと同時代の天文学者力 ール・クレイルでさえドプラの人間性についてあまり知 りませんでした。彼がアントン・シュレッターに書いた 手紙に，“ドプラの人間性についてあまり情報がないの は,ドプラの考え方や彼の人間関係によって説明できる゙ と書いています。ドプラにとって家族はだんだん恼みの 種になり，つねに彼の頭の中にありました。家族と彼と の間に溝ができた原因は，彼があまり話をしなかったか らです。したとしても，ただ科学的な事を話すだけでし た。クレイルはまた，ドプラが話をしない性格は彼の仕 事にも表されているようだと言っています。“仕事におい て，ドプラは，最高の価值は言い表しがたい” と言って おり，“彼は仕事についてほとんどロにしなかった”とク レイルはシュレッタへのいくつかの手紙の中で述べてお り，また "ドプラの最も好んだ発見は最もチャレンジ精 神をかけた発見であり，それは最もよく知られるように なった。もしドプラが胎児であるにとどまらず，それを 手助けする助産婦として彼の着想を世に送り出そうとす る能力をもっていさえいたならば，着想はより応用が効 き，もっと早く現実化していただろう”と書いています。 乏しい情報の断片から，一人の人物像を描くことは易 しいことではありません. トプラの死後 30 年以後に誕生 した孫のアドルフによりかなり粉飾された伝記拉よび個 人の記述がその資料の大部分であるという事実からして,
容易なことではないことがわかります。ドプラについて は若い時の少々ロマンチックな詩や随筆で知ることがで きます。事実，直筆原稿が最近クリスチャン・ドプラ協 会の手に入りました。明らかに，彼は最も私的な事柄に ついても数学的，物理的表現を抑えきれないことをこれ らは裏付けていました。またドプラは, フルート演奏と 切り絵の才能があつたようでした。 8 年間以上，小さな そしてほとんどはつきりとしない断片をモザイクに組み 立てる私の試みは，自分の家族と科学に没頭したはにか み屋で内気な人間の人物像までにはなりませんでしたが, なんとか輪郭までにはわかるようになりました。クリス チャン・トプラは, 大変な勤勉さと決意で, 慢性の病気, 家族を扶養できなくなるのではないかという絶え間ない 不安を克服した努力家でした，控えめで，つつましくそ して正確なことが被の優れた特質でした。もし，私が音 楽で彼の人間性を表現するなら, ザルツブルグでの仲間 の息子であるウオルフガング・アマデウス・モーツァル トではなく，アダージョの物悲しい音色を明白な輝きの きらめきとして変化をもたせるボへミヤのグスタフ・マ ーラーでしょう。

私は物理学者や数学者ではないので, 150 年前クリス チャン・ドプラが少人数の聴衆に対して示したことに対 して，思い切って批判的な評価をくだすことはできませ ん。私としては, ドプラの簡潔明暸な発表は, 2 つの文章 として凝縮されると考えています。彼は明言しています。 “波の進行方向に対して進む船は，同じ時間内に，停船 したり，波に沿って移動している船より多くの衝撃を受 けることをわれわれは体験する。もし，これが水の波に ついて正しいなら，空気や他の波についても必要な修正 を行ない，応用できるのではないか.”さらに彼はこう付 け加えています。“これに対する反論は，ほとんどないと 思われる。”しかし反論は存在しました。 ドプラは, マド ラやペエツバルのような著名な数人の科学者に対して, 自分の最愛の理論を護るために残りの人生を費やしまし た。この論争でドプラが死んだのではありません. 1879 年ベルギー科学アカデミーは，ドプラの理論に反証を試 みた天文学者スペーの功績に対して賞を与えましたが, 最近 1965 年であるが, ブレーメンのカール・シュルツが スペーの理論に対する反論を発表しました. これらの批 評家の中で最も積極的であったのは, 1845 年アムステル ダムとユトレヒト間の鉄道で実験を実施したユトレヒト のオランダ人クリストフ・ヘンドリック・ディデリック・ バイス・バロー教授です。バイズ・バローはホルン奏者 を乗せた貨車を時速 40 マイルで星引できる蒸気機関車 を用い，近づくときと，遠ざかるときの音楽家の演奏に よる音色の明らかなピッチの変化を観察しようと試みま 
した. 残念にも, 2 月の最初の実験では音楽家が雪とあら れのため演奏できないために中断しましたが，その実験 は温暖な 6 月まで延期され, バイス・バローによって観 察された音色の変化は, ドプラの理論の正当性を立証し ました。

ドプラ自身の説が全くの理論上で，かつ虚偽の前提の もとであったため, ドプラの功績が受け入れられたのは， 初めて実験に基づいた事実を論じたときでした，星の輝 きの色彩と強度の変化の応用により, 自分の理論を捕足 し, 天文学からの 9 つの例を提示しました。これらは, 星の速度の効果により星の自然の光が, 白や黄色がかっ た変化として観察されるという誤説に基づいていました。 彼はまた， 40 年前にハーシェルやリッターにより立証さ れた赤外線と紫外線のことについても, 事実, 考慮して いませんでした.

ドプラのこの傑作な研究がなされた年に, 彼は唯 1 人 の反対票に対し 9 人の賛成票を得てロイヤルボへミアン 科学会の正会員として選ばれました. 彼の数学と代数の 教科書の初版が出版され, その時彼の 4 番目の子供のべ ルタが最初の住居であるウオベティホドボラ 799 番地の 家の 1 階で生まれました。この家にドプラ家はプラ八を 離れる時まで住んでいましたが，そこで彼らの 5 番目の 末っ子ハーマンが 1844 年に生まれており, 未だ当時のま ま残っています。このドプラ原理の輝かしい記念日に, この気取らない物理学者がこの町で過ごした実りの多い 日々にふさわしい思い出を提供するために，この家を保 存復元しょうとするのはあまりにも望み過ぎでしょう か? このような動きは確かにクリスチャンドプラ協会や その他の援助者の活発な活動に見受けられました。

ドプラ家は, 彼がバンスカ・スティアブニカの採鉱や 森林の専門学校の数学と力学の教授に約束された 1847 年の末にプラ八を離れました. 彼のそこでの任務は 1848 年の大革命の年までしか続かず，その間，教授であった ドプラは, ウイーンにある物理学の帝国協会の正会員に 選ばれました.また 1348 年にそれが創設された 500 年記 念の祝宴に, この有名で歴史ある大学の哲学の教授団よ り名誉博士号を与えられました。おもしろいことに，今 日では当然ですが，医学界においても博士号に值するの で医学博士も与えるべきだという声もでていましたが, 当時は何を基準にして博士号を与えてよいのかわかりま せんでした，当時の政治不安がプラ八にまで広がったこ とにより，授与式は 8 月に予定されていましたが早々に 延期され，ついには中止となりました。この波乱含みの 年の末に, ドプラはウイーンの工科大学におけるシモン スタンフフアーの後継者との任命を受けました。ここで の彼の任務は約 1 年続きましたが, 1850 年 1 月 17 日
に皇帝フランツ・ヨセフは, ウイーンの皇帝大学での物 理学教室の資金提供を許可する命令を出しており，ドプ ラを実験物埋学の責任者兼教授として任命しました。

クリスチャン・ドプラはその時彼の人生の頂点に到達 しましたが, 運命は家族と暮らしていたエルドバーグ郊 外のウイーンのハプトシュトラッセにある 104 番の家で, 彼が新しい研究室を起こすだけのわずかな時間を残すの みとなっていました. 当時 28 歳であった聖アウグスチヌ ス派修道士ヨハン・グレゴール・メンデルは, 大学で勉 強するために筆記試験および口頭試間を受けましたが, ドプラは遺伝学の基礎を積んでいた彼を入学させること に積極的でなく,メンデルは翌年まで大学に入学できま せんでした。 そして，ドプラは引き続き健康を損ねてい たため, 物理学の教育は彼の助手達に受け継がれていき ました. 1852 年 11 月には, 彼の病状はさらに悪化したた めベニスでの 6 力月間の療養を余儀なくされました，彼 は彼の友達のフランツ・エクスナーとその地へ旅立ち, 二度と戻ることはありませんでした。

ドプラは, 1853 年 3 月 17 日朝 5 時頃, 最後の日々を過 ごしたウイーンにて, 8 歳から 15 歳の 5 人の子供を残 し, 愛する妻の腕の中で苦しまず静かにこの世を去りま した. ブラゴラのサン・ジョバンニ教会の牧師が毎日散 歩したピオバンの丘を一望できる部屋で亡くなりました. 彼は, 後にベニスの物理学者達が記念碑を建てた聖ミハ エル島のお墓に葬られました. しかし私達が集まってい るこの会は, 偉大な科学者の死を悼むための記念称賛会 ではなく, また 150 年前ここで行われた会議をここで記 念するためだけに集まっているのでもありません。これは ドプラの理論的観察であった “二重星の放つ光の色” 以 来, 150 年間受け継がれてきた知識と進歩や, 今後の新し い技術やそれらから得られるであろう恩恵を祝うためで す．私は名誉にも，クリスチャン・ドプラが晚年関係の 深かった 3 つの大学の教授, 科学者, 技術者方が推ま りになっているこの会議に招待いただきました，その大 学とは, ドプラに名誉博士号を与え, さらに彼が英国学 士院の会議に出席したシャルル大学, 10 年間ドプラが教 鞭をとっていたチェコスロバキア大学（前プラ八工科大 学),ドプラが会員であろことを誇りとしていた王室ボへ ミア科学院を継承するチェコスロバキア科学アカデミー であり，それぞれ有名かつ歴史のある大学であります。 この点においてあなた方みなさんは, ドプラの歩みの後 継者であり, 御自身の各分野でのドプラの功績の重要性 を御存じでありましょう。

また，世界中のさまざまな国のさまぎまな科学の分野 において, ドブラの歩みを後継する有名無名の無数の学 者がいることも御存じでしょう。一時はあのアイザッ 
ク・ニュートン博士が理事長であったケンブリッジ大学 で数学の教授職をとられていたズテファン・ホーキング 氏に, クリスチヤン・ドプラ基金の名誉特別会員賞を送 らさせていただいたことを, 今日この栄えある場でみな さんにご報告できることは大きな喜びであります，彼の 研究, 彼の言うところの “物事すべてのための理論”は, 彼の健康が大変に悪い時期にあるにもかかわらず，すば らしい研究であります.

医学分野においてドプラの原理の応用は, 体内の血管 を流れる血流を痛みなくかつ安全に測ることを可能とし た超音波法です，今日，ドプラ法の超音波装置で体のす みずみまで見ることができるといっても言い過ぎではな いでしょう，実際生まれる前から，胎児の血流や心音を 超音波で測れるので, この技術は藏器移植にとって重要 な初期の脳死判定にますます利用されています.・ドプラ は，胎児から人間の死に至るまで貢献しているのであり ます。

妊娠中の婦人に対する検查の重要性は, 私が 1803年に ザルツブルグでドプラが生まれた記録を探している最中に
認識しました。その分厚い記録書の至るところに，出産 時死亡していた子供を意味する十字架の印がページの半 分をも占めていました.今日その率は 1000 人中約 6 人の 割合です。ドプラ心臟超音波法は，30４0 歳のストレス の多い年代に一番多い死因である心臓の弁障害の発見を 可能にしました. ドプラ断層法は生死を決める血栓症の 診断や，血管外科医の手術技術の向上をもたらしました。 脳の中を見ることができるドプラ超音波断層図, その技 術は私が開拓者的役割を誇っているのですが, 脳の中の 血液の流れを手術することなく計測可能とし, 高齢者に 起こりがちな脳卒中の治療と予防に貢献しています。ま た鎌状赤血球貧血症の黒人少年に抒きやすい脳卒中の予 防にも一役かっています。私達が今日記念します石屋の 息子であったクリスチャン・アンドリアス・ドプラのこ の功績は病気に対する科学の勝利です，もしドプラが今 日謙虚にまた誇ることなく成し遂げた彼の天文物理学の 原理を利用した数々の業績を見たらきっと驚くことでし ょう.

（訳：和田高士） 